\title{
Pengelompokkan Karakteristik Iklan UMKM Menggunakan Analisis Cluster
}

\author{
Mutia Tri Satya \\ Sekolah Tinggi Ilmu Ekonomi (STIE) Ekuitas \\ Mutia.satya@gmail.com \\ Novi Kadarini Rahayu \\ Sekolah Tinggi Ilmu Ekonomi (STIE) Ekuitas \\ trengginasina@gmail.com
}

\author{
Abdul Fidayan \\ Universitas Sangga Buana \\ afidayan@yahoo.com
}

\begin{abstract}
Abstrak Tantangan yang dihadapi UMKM saat ini adalah meningkatkan produktifitas dan daya saing agar dapat meningkatkan pangsa pasarnya, serta mendiversifikasi dan mendiferensiasikan produknya di pasar dalam negeri maupun luar negeri. Permasalahan umum yang dihadapi UMKM, antara lain adanya keterbatasan kepemilikan dan akses permodalan, keterbatasan pemasaran dan promosi, serta kemitraan. Tujuan dari penelitian ini adalah membuat strategi iklan yang dilakukan oleh UMKM. Dimana sebelum membuat strategi, iklan diklasifikasikan sesuai dengan karakteristiknya dengan menggunakan analisis cluster. Dengan hasil analisis dan strategi ini setidaknya membantu para UMKM untuk membuat strategi dalam mempromosikan produknya sehingga akan lebih dikenal lagi oleh konsumen lebih luas dan dampaknya akan meningkatkan penjualan dan keuntungan. Urgensi penelitian sangat penting sekali, mengingat UMKM sangat lemah sekali dalam hal promosi. Strategi promosi yang dilakukan kadang tidak tepat, karena pelaku usaha kurang mengenal karakteristik setiap iklan yang dibuat. Penelitian ini belum pernah ada yang melakukan, jadi ini merupakan penelitian yang pertama yang hasilnya diharapkan bsa membantu para UMKM dalam membuat strategi iklan yang lebih menarik.
\end{abstract}

Kata Kunci $\quad U M K M$, Promosi Iklan, dan Strategi

\section{PENDAHULUAN}

Iklan merupakan bagian dari promosi yang dapat dimanfaatkan secara efektif untuk membangun citra jangka panjang produk maupun perusahaan dan juga dapat memicu pembelian segera (Tjiptono, 1997). Iklan berusaha untuk memberikan informasi, membujuk, dan menyakinkan. Jika dibandingkan dengan bentuk komunikasi lain, iklan 
adalah suatu sarana komunikasi yang dipergunakan dalam dunia perdagangan oleh produsen terhadap konsumen yang meraih lebih banyak calon pembeli dengan biaya lebih rendah, dalam waktu yang lebih singkat, sedangkan pengaruhnya akan melekat lebih lama pada ingatan pemirsa. Periklanan merupakan fenomena bisnis modern yang memanfaatkan media massa untuk menawarkan suatu barang maupun jasa.

Seiring berjalannya waktu, media untuk beriklan semakin banyak mulai dari koran,majalah, radio, televisi hingga melalui sosial media. Saat ini promosi melalui media internet sangat digemari oleh pelaku usaha yang kebanyakan adalah sektor UMKM. Salah satu media yang termasuk media internet adalah media sosial. Penggunaan media sosial sebagai alat untuk beriklan lebih digemari karena cenderung memiliki biaya yang lebih murah dibandingkan dengan media promosi yang lain. Menurut (Khairani, Soviyant, \& Aznuriyandi, 2018) media sosial memiliki beberapa kelebihan dibandingkan dengan media terdahulu yaitu media berbagi aktifitas, media berbagi pengetahuan, media untuk memperluas jejaring dan komunitas dan media penyebaran informasi. Beberapa media sosial yang sering digunakan sebagai media iklan adalah Facebook, Twitter, Instagram, Line, dsb.

Untuk menumbuhkan minat konsumen mencoba dan membeli produk UMKM, diperlukan upaya berbagai strategi pemasaran yang efektif salah satunya dengan kegiatan promosi (Khairani, Soviyant, \& Aznuriyandi, 2018). Perencanaan dan pemilihan alat atau media komunikasi pemasaran sangat penting, hal tersebut bertujuan untuk memaksimalkan informasi yang akan disampaikan kepada target atau calon konsumen. Penyebaran informasi produk dengan cara yang unik dan menarik mampu mempengaruhi citra produk di mata masyarakat Hal tersebut juga akan menguatkan brand serta meningkatkan tingkat penjualan.

Tantangan yang dihadapi UMKM saat ini adalah meningkatkan produktifitas dan daya saing agar dapat meningkatkan pangsa pasarnya, serta mendiversifikasi dan mendiferensiasikan produknya di pasar dalam negeri maupun luar negeri. Permasalahan umum yang dihadapi UMKM, antara lain adanya keterbatasan kepemilikan dan akses permodalan, keterbatasan pemasaran, dan kemitraan. Permasalahan permodalan sedikit banyak sudah teratasi dengan berbagai jenis program pembiayaan. Namun demikian, masalah pemasaran yang dialami UMKM belum mendapatkan perhatian cukup dari Pemerintah Daerah (Pemda) terutama dalam hal promosi penjualan. Hal ini tampak dari belum jelasnya kegiatan Pemda dalam menyediakan sarana, penguatan, serta dukungan di bidang informasi khususnya dalam kegiatan periklanan dengan melibatkan UMKM mulai dari tahap pembuatan keputusan, pelaksanaan, tahap menikmati hasil, dan evaluasi. Pada dasarnya tujuan iklan untuk mempengaruhi khalayak agar percaya dengan produk yang ditawarkan, hal ini disebabkan potensi iklan yang luar biasa dalam menciptakan opini dan persepsi masyarakat. Sebuah iklan diharapkan mampu menjadi jembatan untuk menanamkan kepercayaan pada masyarakat. Iklan bisa dikatakan berhasil apabila timbul sebuah kepercayaan dalam diri khalayak terhadap suatu produk dan dapat mendorong konsumen untuk menggunakan produk maupun jasa yang ditawarkan dari perusahaan periklanan.

Target atau audiens sasaran iklan terbagi menurut golongan dari usia, dari segi usia dewasa terdiri dari usia di atas 55 tahun, 35 - 45 tahun, dari segi pendidikan terdiri dari universitas sampai sekolah dasar, dan sisanya tidak di kategorikan yaitu anak - anak (Nielsen, 1985). Dari segi usia tersebut pengiklan produk harus menentukan intensitas iklan terhadap sasaran yang dituju. Melihat akan pentingnya pemilahan usia akan iklan, 
produsen benar-benar harus mempertimbangkan akan tepatnya iklan sesuai tepat sasaran. Media informasi iklan diciptakan agar dapat menarik khalayak dan orisinil, serta mempunyai karakteristik dan persuasif sehingga konsumen secara sukarela untuk melakukan tindakan seperti tindakan yang ada pada iklan (Jefkins, 1997). Dengan gaya meniru itu tadi secara tidak sengaja konsumen akan terpikat ataupun tertarik untuk membeli serta memakai produk yang diiklankan tersebut. Respon dengan cara senang atau tidak menyenangkan terhadap rangsangan iklan saat senang atau tidak terhadap iklan pada saat penayangan iklan merupakan sikap terhadap iklan (MacKenzie \& Lutz, 1989). Persepsi individual konsumen akan bisa dilihat dengan penangkapan dari iklan yang akan ditayangkan di waktu yang tepat. Untuk itu penempatan waktu penayangan iklan seakan akan menjadi pertimbangan utama dari pada cara pemasaran iklan produk baru tersebut.

\section{LANDASAN TEORI}

\section{A. 1. Periklanan}

Periklanan adalah alat penting yang digunakan oleh perusahaan untuk melancarkan komunikasi persuasif terhadap pembeli dan masyarakat yang ditargetkan. Pada dasarnya periklanan merupakan salah satu bentuk khusus komunikasi untuk memenuhi fungsi pemasaran. Periklanan harus mampu membujuk konsumen supaya berpikir sedemikian rupa sesuai dengan strategi pemasaran perusahaan untuk mendapatkan penjualan dan keuntungan (Rina, 2014). Menurut Lee \& Johnson (2011) daya tarik periklanan merujuk pada basis atau pendekatan yang digunakan dalam iklan untuk menarik perhatian atau minat para konsumen dan atau untuk mempengaruhi perasaan-perasaan mereka terhadap produk, jasa, atau gagasan.

\section{Fungsi Periklanan}

Secara umum, periklanan ini bernilai karena memiliki lima fungsi pentingn komunikasi yaitu (1) memberi informasi, (2) memberi pengaruh,(3) mengingatkan dan memperlihatkan keistimewaan, (4) menambah nilai, dan (5) membantu upaya perusahaan (Shimp T. A., 2014)

1. Memberikan informasi

Salah satu fungsi ut

ama iklan adalah mempublikasikan merek, iklan membuat konsumen mengenal merek suatu produk, mendidik mereka megenai keistimewaan dan manfaat merek, dan memfasilitasi kreativitas citra positif merek tersebut. Karena iklan merupakan bentuk komunikasi yang paling efisien dan memiliki kemampuan untuk menjangkau banyak konsumen dengan biaya yang cukup rendah, iklan memudahkan untuk memperkenalkan merek baru dan meningkatkan permintaan merek yang sudah ada, tentunya dengan meningkatkan kesadaran tinggi konsuen akan suatu merek atau top-of- kind awareness (TOMA) bagi merek yang telah mapan dalam kategori produk yang matang. Iklan memberikan informasi yang bernilai baik untuk merek yang diptomosikan dan konsumen dengan mengajarkan penggunaan baru untuk merek yang sudah ada.

2. Memberi Pengaruh

Iklan yang efektif mempengaruhi target konsumen untuk mencoba produk atau jasa yang ditawarkan. Terkadang iklan mempengaruhi permintaan dasar, yaitu menciptakan permintaan untuk seluruh kategori produknya. Lebih sering lagi iklan berusaha untuk membangun permintaan sekunder untuk permintaan merek 
perusahaan, periklanan oleh perusahaan B2C dan B2B menyediakan alasan yang tepat dan ketertarikan secara emosional kepada konsumen dan pelanggan untuk segera mencoba melakukan pembelian pada merk ini dibandingkan yang lainnya.

3. Mengingatkan dan Meningkatkan Kesadaran akan Merek

Iklan membuat merek perusahaan selalu ada dalam pikiran konsumen, ketika permintaan meningkat terhadap produk terkait yang diiklankan, pengaruh iklan masa lalu membuat adanya kemungkinan konsumen akan menjadikan produk itu sebagai kandidat produk yang akan dibeli. Ini yang membuat merek menjadi lebih menonjol. Memperkaya memori perihal merek akan membuat merek secara tidak langsung muncul dalam ingatan dalam situasi pemilihan yang relevan. Iklan yang efektif juga akan meningkatkn ketertarikan pada merek yang telah matang dan dengan demikian akan memberi merek tersebut meski sebenarnya tidak memilihnya.

4. Menambah Nilai

Iklan menambah nilai merek dengan memengaruhi persepsi. Iklan yang efektif menyebabkan merek dipandang lebih elegan, lebih bergaya, lebih prestisius, lebih berkualitas, dan lainnya. Iklan yang berkualias dengan mempengaruhi persepsi kualitas dan persepsi lainnya dapat meningkatkan pangsa pasar dan keuntungan yang lebih besar. Dengan menambah nilai, iklan dapat menghasilkan volume penjualan, pendapatan, dan keuntungan yang lebih banyak serta mengurangi risiko arus kas masuk yang tidak tentu.

5. Membantu Upaya Lain Perusahaan

Iklan mungkin digunakan sebagai sarana unruk menyampaikan adanya diskon atau jalan untuk menarik perhatian konsumen pada media promosi lainnya. Pesan krusial lainnya adalah untuk membantu tim penjualan. Iklan menjual lebih dulu produk sebuah perusahaan dan menyediakan perkenalan dan pendahuluan bagian penjualan saat berhadapan langsung dan pribadi dengan konsumen yang potensial. Iklan juga dapat digunakan untuk membantu konsumen mengenali kemasan produk di toko dan lebih mengenali nilai merek dari iklan yang ada ditelevisi atau media lainnya. Iklan juga dapat mempercepat penyesuaian harga. Konsumen yang mengetahui akan lebih renponsif terhadap harga yang ditawarkan ditingkat eceran.

\section{Frekuensi Penayangan Iklan}

Pesan iklan yang baik hendaknya disampaikan berulang- ulang melalui medianya. Perulangan pesan di radio berkali-kali, penayangan di televisi pun demikian, kekerapan muncul dihalaman surat kabar, atau majalah disetiap waktu terbit. Artinya dengan demikian mudah mengingatkan pada waktu tertentu, halaman tertentu, iklan tertentu akan muncul pada media. Pemakai secara refleks cepat mengingatnya. Penampilan berkali-kali pada waktu yang sama dan di halaman yang sama mengakibatkan setiap orang mengingatnya (Liliweri, 1992)

Waktu-waktu dalam periklanan televisi seperti halnya dalam radio sehari ini disebut sebagai bagian hari (day part). Menurut (Shimp, 2003) day part dibagi menjadi tiga bagian waktu yaitu waktu utama (prime time), siang hari (day time), dan waktu tambahan (fringe time) yang masing-masing mempunyai kekuatan dan kelemahan tersendiri.

1. Waktu utama (prime time), periode waktu antara pukul 20:00 dan 23:00 atau antara pukul 19:00 dan 22:00. Program terbaik dan termahal ditayangkan selama periode ini. 
2. Siang hari (day time), periode yang dimulai dengan tayangan berita di pagi hari (subuh) berlangsung sampai pukul 16:30. Day time berisi program- program baik untuk dewasa maupun anak- anak.

3. Waktu tambahan (fringe time), masa sebelum dan sesudah waktu utama (prime time). Awal fringe time dimulai pada sore hari dan khususnya ditujukan pada anak-anak tetapi menjadi lebih berorientasi kepada orang dewasa bilamana waktu utama mendekat. Waktu tambahan di larut malam ditujukan untuk para dewasa muda

Frekuensi yang tinggi jika tidak didukung dengan waktu penayangan yang tepat akan terasa sia-sia karena iklan tidak akan menjangkau segmen pasar yang tepat. Periode waktu penayangan iklan sangat penting untuk diperhatikan, terutama pada priode prime time. Penayangan iklan harus dilakukan dengan frekuensi yang cukup (Sihombing, 2010). Suatu iklan baru akan efektif jika dilihat rata-rata tiga kali. Jika hanya satu atau dua kali dianggap belum memberi dampak signifikan karena tingkat perhatian audiens masih rendah atau belum terbentuk. Akan tetapi terlalu banyak pengulangan dapat menimbulkan efek yang merugikan, mengurangi keefektifan iklan (Indriyanti \& ilhalauw, 2002). Fenomena ini disebut kejemuan akan iklan (advertising wearout).

\section{Jenis Iklan}

Tujuan iklan harus mengalir dari keputusan sebelumnya tentang pasar sasaran, positioning merek, dan program pemasaran. Menurut Kotler \& Keller, (2016) berdasarkan tujuannya, iklan dapat dibagi menjadi beberapa jenis, diantaranya adalah :

1. Iklan Informatif

Iklan informatif bertujuan menciptakan kesadaran merek dan pengetahuan tentang produk atau fitur baru produk yang ada.

2. Iklan persuasive

Iklan ini bertujuan untuk menciptakan kesukaan, preferensi, keyakinan, dan pembelian produk atau jasa.

3. Iklan pengingat (Reminder)

Iklan pengingat bertujuan untuk menstimulasikan pembelian berulang produk dan jasa.

4. Iklan Penguat (Reinforcement)

Iklan penguat bertujuan untuk meyakinkan pembeli bahwa mereka melakukan pilihan yang tepat.

\section{METODOLOGI PENELITIAN}

Jenis penelitian ini adalah penelitian menggunakan metode klaster yaitu metode statistic yang digunakan untuk mengelompokkan subjek atau objek penelitian dalam jumlah banyak menjadi kelompok - kelompok dalam jumlah kecil yang bersifat homogeny dan mutually exclusive, yang disebut klaster. Sehingga penelitian ini juga bisa disebut penelitian kasus atau study kasus (case study) dengan pendekatan deskriptifkuantitatif.

Terdapat 5 variabel yang digunakan dalam penelitian ini dengan masing-masing indikator variabel yang digunakan, yaitu media iklan (X1) dengan 4 indikator variabel, Iklan Informatif (X2) dengan 6 indikator variabel, Iklan Persuasif (X3) dengan 6 indikator vaiabel, iklan reminder (X3) dengan 4 indikator variabel dan Iklan Penguat dengan 1 indikator variabel. 
Tabel 3. 1 Indikator Variabel Penelitian

\begin{tabular}{|l|l|}
\hline \multicolumn{1}{|c|}{ Media Iklan } \\
\hline 1 & Menggunakan media cetak sebagai alat promosi \\
\hline 2 & Menggunakan media elektronik sebagai alat promosi \\
\hline 3 & Menggunakan media sosial sebagai alat promosi \\
\hline 4 & Menggunakan sistem mouth to mouth sebagai alat promosi \\
\hline
\end{tabular}

\begin{tabular}{|l|l|}
\hline \multicolumn{2}{|c|}{ Iklan Informatif } \\
\hline 1 & Bertujuan untuk memperkenalkan produk baru \\
\hline 2 & Bertujuan untuk menginformasikan harga baru \\
\hline 3 & Bertujuan untuk menginformasikan kemasan produk \\
\hline 4 & Bertujuan untuk menjelaskan cara kerja produk \\
\hline 5 & Bertujuan untuk mengurangi keraguan/ketakutan konsumen untuk membeli produk \\
\hline 6 & Bertujuan untuk mengkoreksi kesalahan pada produk sebelumnya \\
\hline
\end{tabular}

\begin{tabular}{|l|l|}
\hline \multicolumn{1}{|c|}{ Iklan Persuasif } \\
\hline 1 & Bertujuan untuk menimbulkan rasa suka konsumen terhadap produk saya \\
\hline 2 & Bertujuan untuk meyakinkan konsumen agar membeli produk saya \\
\hline 3 & Bertujuan untuk membuat konsumen memilih produk saya dibandingkan dengan produk lain \\
\hline 4 & Iklan berisi anjuran untuk membeli produk saya \\
\hline 5 & Bertujuan untuk mengubah persepsi konsumen terhadap produk saya \\
\hline 6 & Bertujuan membujuk konsumen untuk membeli produk saya saat ini juga \\
\hline
\end{tabular}

\begin{tabular}{|l|l|}
\hline \multicolumn{2}{|c|}{ Iklan Reminder } \\
\hline 1 & Bertujuan untuk mendorong pembelian ulang produk saya \\
\hline 2 & Bertujuan untuk mengingatkan bahwa produk saya akan sangat dibutuhkan dalam waktu dekat \\
\hline 3 & Bertujuan untuk menjaga kesadaran akan adanya produk saya \\
\hline 4 & Bertujuan untuk menjalin hubungan baik dengan konsumen \\
\hline
\end{tabular}

\section{Iklan Penguat}

\begin{tabular}{l|l}
\hline 1 & Bertujuan untuk meyakinkan pembeli bahwa mereka melakukan pilihan yang tepat
\end{tabular}

Sama dengan analisis factor, analisis cluster (cluster analysis) termasuk pada Interdependes Techniques. Namun ada perbedaan mendasar di antara kedua alat analisis multivariate ini. Jika analisis factor ( $\mathrm{R}$ factor analysis) bertujuan mereduksi variable, analisis cluster ( $Q$ factor analysis) lebih bertujuan mengelompokkan isi variabel, walaupun bisa juga disertai dengan pengelompokan variabel. Dalam terminology SPSS, 
analisis factor adalah perlakuan terhadap kolom, sedangkan analisis cluster adalah perlakuan terhadap baris.

Untuk menganalisis cluster, diperlukan beberapa proses sebagai berikut :

1. Mengukur kesamaan antar objek (similarity)

Sesuai prinsip analisis cluster yang mengelompokkan objek yang mempunyai kemiripan, proses pertama adalah mengukur seberapa jauh ada kesamaan antar objek. Metode yang digunakan :

- Mengukur kolerasi antar sepasang objek pada beberapa variabel.

- Mengukur jarak (distance) antara dua objek.

2. Membuat cluster

Metode cluster yang digunakan adalah hierarchial clustering dimana data dikelompokkan melalui suatu bbagan yang berupa hierarki, dimana terdapat penggabugan dua grup yang terdekat disetiap iterasinya ataupun pembagian dari selutuh set data kedalam cluster.

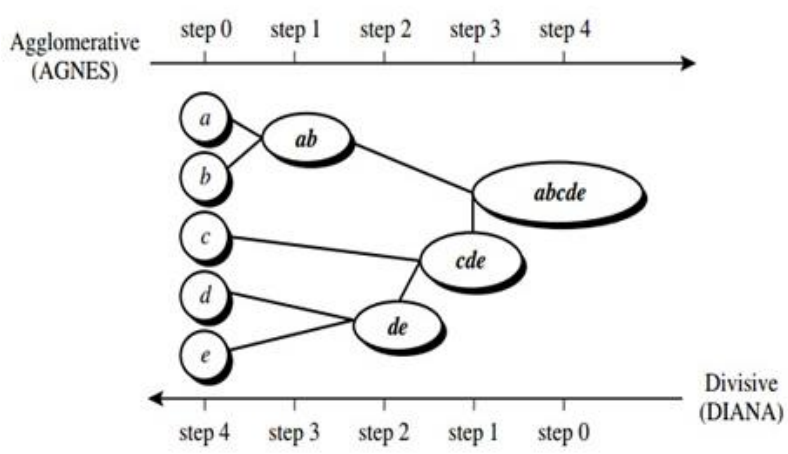

Gambar 3. 1 Analisis Cluster

\section{HASIL PENELITIAN}

Responden dalam penelitian ini adalah UMKM berjenis kuliner yang telah menerbitkan iklan. Pengumpulan data dilakukan dengan cara penyebaran kuesioner dengan total responden berjumlah 30 UMKM yang berada di Kota Bandung dan bergerak dalam bidang kuliner. Daftar UMKM yang menjadi responden dalam penelitian ini adalah:

Tabel 4. 1 Datar Sampel Penelitian

\begin{tabular}{|l|l|l|}
\hline 1. Wakacao & 11. Roti Manis & 21. Kopi Doeloe \\
\hline 2. Katalogsweetshaley & 12. Bubur Ayam Jalaprang & 22. Pagar Putih \\
\hline 3. Dapur Neng Monica & 13. Dra' Cook & 23. Pojok Buhee \\
\hline 4. Sedia Kopi & 14. Milk Bar & 24. Kantin Hijau \\
\hline 5. Jameela Kitchen & 15. Dapur Suka Suka & 25. Nyo Nyo Milk C \\
\hline 6. Jihan Salad & 16. Kue Balok & 26. Seblak Nanay's \\
\hline 7. Kongkowrongok & 17. Seblak Cihuy & 27. Salad by Sarah Kitchen \\
\hline 8. Bagi Kopi & 18. Salad Buah Salada & 28. Cireng Domba \\
\hline 9. Selly Food & 19. Rumah Pasta dan Pastry & 29. Bolen Geulis \\
\hline 10. Dapur Vaedah & 20. Seafood Cigadung & 30. Windy's Risoles \\
\hline
\end{tabular}

Semua data sejumlah 30 objek telah diproses tanpa ada data yang hilang, hal tersebut dapat dilihat pada tabel dibawah ini. 
Tabel 4. 2 Case Processing Summary

Case Processing Summary ${ }^{\mathrm{a}}$

\begin{tabular}{|c|c|c|c|c|c|}
\hline \multicolumn{6}{|c|}{ Cases } \\
\hline \multicolumn{2}{|c|}{ Valid } & \multicolumn{2}{|c|}{ Missing } & \multicolumn{2}{|c|}{ Total } \\
\hline $\mathrm{N}$ & Percent & $\mathrm{N}$ & Percent & $\mathrm{N}$ & Percent \\
\hline 30 & $100,0 \%$ & 0 & $0,0 \%$ & 30 & $100,0 \%$ \\
\hline
\end{tabular}

a. Squared Euclidean Distance used

Dari hasil penelitian yang dilakukan menunjukkan bahwa sekitar 97\% UMKM lebih sering menggunakan sosial media sebagai alat untuk menyebarkan iklan media sosial yang sering digunakan adalah instagram, website, dan facebook. 40\% menggunakan media elektronik seperti komputer dan handphone atau bahkan ada yang telah mengiklankan produknya melalui radio. $8 \%$ melakukan promosi dengan menyebarkan informasi melalui mulut ke mulut, serta $2 \%$ menggunakan media cetak seperti, brosur dan pamflet. Sedangkan jenis iklan yang banyak digunakan oleh UMKM adalah iklan persuasif yang bertujuan untuk menarik minat calon pelanggan potensial atau konsumen untuk membeli produknya. Hal tersebut bersifat wajar karena pada dasarnya UMKM merupakan bisnis yang sedang berkembang dan ingin mencari keuntungan yang cukup besar agar bisnisnya tetap berjalan.

Tabel 4. 3 Agglomeration Schedule

Agglomeration Schedule

\begin{tabular}{|c|c|c|c|c|c|c|}
\hline \multirow[b]{2}{*}{ Stage } & \multicolumn{2}{|c|}{ Cluster Combined } & \multirow[b]{2}{*}{ Coefficients } & \multicolumn{2}{|c|}{ Stage Cluster First Appears } & \multirow[b]{2}{*}{ Next Stage } \\
\hline & Cluster 1 & Cluster 2 & & Cluster 1 & Cluster 2 & \\
\hline 1 & 8 & 27 & 4,797 & 0 & 0 & 6 \\
\hline 2 & 14 & 17 & 5,533 & 0 & 0 & 13 \\
\hline 3 & 16 & 25 & 5,965 & 0 & 0 & 8 \\
\hline 4 & 19 & 28 & 6,217 & 0 & 0 & 10 \\
\hline 5 & 18 & 21 & 7,477 & 0 & 0 & 10 \\
\hline 6 & 2 & 8 & 8,700 & 0 & 1 & 8 \\
\hline 7 & 15 & 29 & 9,397 & 0 & 0 & 14 \\
\hline 8 & 2 & 16 & 12,065 & 6 & 3 & 13 \\
\hline 9 & 23 & 24 & 12,464 & 0 & 0 & 23 \\
\hline 10 & 18 & 19 & 13,519 & 5 & 4 & 14 \\
\hline 11 & 26 & 30 & 13,557 & 0 & 0 & 18 \\
\hline 12 & 13 & 20 & 16,686 & 0 & 0 & 15 \\
\hline 13 & 2 & 14 & 16,894 & 8 & 2 & 19 \\
\hline 14 & 15 & 18 & 18,340 & 7 & 10 & 16 \\
\hline 15 & 10 & 13 & 19,537 & 0 & 12 & 20 \\
\hline 16 & 15 & 22 & 21,239 & 14 & 0 & 18 \\
\hline
\end{tabular}




\begin{tabular}{|r|r|r|r|r|r|r|}
17 & 7 & 12 & 21,510 & 0 & 0 & 21 \\
18 & 15 & 26 & 21,771 & 16 & 11 & 20 \\
19 & 2 & 6 & 22,778 & 13 & 0 & 21 \\
20 & 10 & 15 & 25,019 & 15 & 18 & 22 \\
21 & 2 & 7 & 27,823 & 19 & 17 & 22 \\
22 & 2 & 10 & 32,491 & 21 & 20 & 24 \\
23 & 4 & 23 & 37,167 & 0 & 9 & 25 \\
24 & 2 & 9 & 44,457 & 22 & 0 & 26 \\
25 & 4 & 11 & 46,320 & 23 & 0 & 26 \\
26 & 2 & 4 & 46,834 & 24 & 25 & 28 \\
27 & 1 & 3 & 49,959 & 0 & 0 & 29 \\
28 & 2 & 5 & 56,544 & 26 & 0 & 29 \\
29 & 1 & 2 & 88,926 & 27 & 28 & 0 \\
\hline
\end{tabular}

Tabel di atas merupakan hasil proses clustering dengan metode Between Group Linkage. Setelah variabel diukur dengan jarak euclidean, maka dilakukan pengelompokkan yang dilakukan secara bertingkat.

- Stage 1 : terbentuk 1 cluster yang beranggotakan UMKM no 8 dan 27 yaitu Bagi Kopi dan Salad by Sarah Kitchen dengan jarak 4,797. Karena proses aglomerasi dimulai dari 2 obyek yang terdekat, maka jarak tersebut adalah jarak terdekat dari sekian kombinasi jarang 30 obyek yang ada. Pada kolom next stage terlihat angka 6. Hal ini berarti clustering selanjutnya dilakukan dengan melihat stage 6 , dengan penjelasan sebagai berikut.

- Stage ke 6 terlihat obyek ke 2 (Katalogsweetshaley) membentuk cluster dengan Bagi Kopi. Dengan demikian sekarang cluster terdiri dari 3 obyek, Bagi Kopi, Salad by Sarah Kitchen, dan Katalogsweetshaley. Sedangkan arak sebesar 8,700 merupakan jatak rata-rata obyek terakhir yang bergabung dengan 2 obyek sebelumnya. Seperti tampakdalam proximity matrix dan dapat dihitung sebagai berikut :

- Jarak Bagi Kopi dan katalogsweetshaley = 8,700

○ Jarak Bagi Kopi dan Salad by Sarah Kitchen $=4,797$

- Jarak rata-rata $=(8,700+4,797) / 2=6,7458$

- Stage 2 : terjadi pembentukkan cluster Milk Bar dan Seblak Cihuy berjarak 5,533, yang berlanjut ke stage 13 .

- Begitu seterusnya dari stage 3 dilanjutkan ke stage 29, sampai ke stage terakhir.

Dalam bentuk grafik jarak yang dihasilkan dari proses clurstering dapat ditampilkan sebagai berikut: 


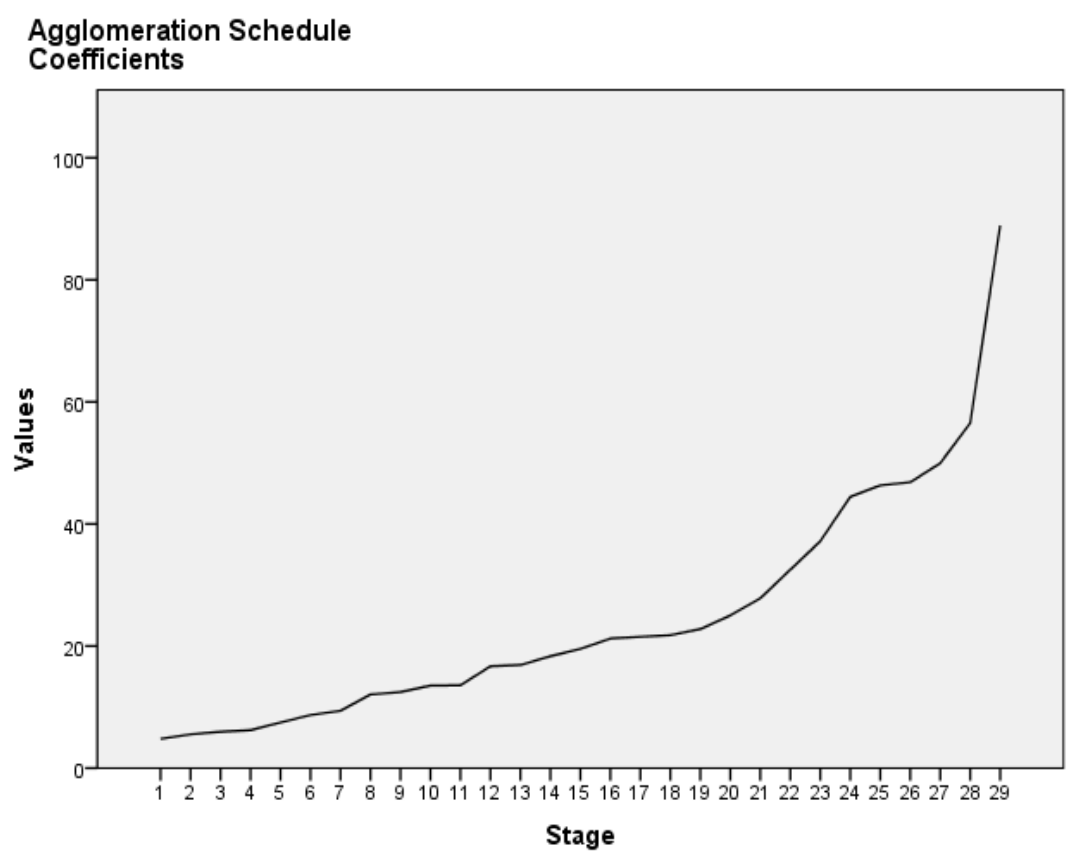

Gambar 4. 1 Grafik jarak sampel

Proses aflomerasi pada akhirnya akan menyatukan semua obyek menjadi satu cluster. Hanya saja dalam prosesnya dihasilkan beberapa cluster dengan masing-masing aggotanya. Perincian jumlah cluster dengan anggota yang terbenuk dapat dilihat pada tabel output berikut ini :

Tabel 4. 4 Pengelompokkan Cluster

\begin{tabular}{|l|r|r|r|}
\hline \multicolumn{4}{|c}{ Cluster Membership } \\
\hline Case & 4 Clusters & 3 Clusters & 2 Clusters \\
\hline 1:Wakacao & 1 & 1 & 1 \\
2:Katalogswee & 2 & 2 & 2 \\
3:Dapur Neng & 3 & 1 & 1 \\
4:Sedia Kopi & 2 & 2 & 2 \\
5:Jameela Kit & 4 & 3 & 2 \\
6:Jihan Salad & 2 & 2 & 2 \\
7:Kongkowrong & 2 & 2 & 2 \\
8:Bagi Kopi & 2 & 2 & 2 \\
9:Selly Food & 2 & 2 & 2 \\
10:Dapur Vaeda & 2 & 2 & 2 \\
11:Roti Manis & 2 & 2 & 2 \\
12:Bubur ayam & 2 & 2 & 2 \\
13:Dra' Cook & 2 & 2 & 2 \\
14:Milk Bar & 2 & 2 & 2 \\
\hline
\end{tabular}




\begin{tabular}{|l|l|l|l|} 
15:Dapur Suka & 2 & 2 & 2 \\
16:Kue Balok & 2 & 2 \\
17:Seblak Cihu & 2 & 2 \\
18:Salad Buah & 2 & 2 & 2 \\
19:Rumah Pasta & 2 & 2 & 2 \\
20:Seafood Cig & 2 & 2 & 2 \\
21:Kopi Doeloe & 2 & 2 & 2 \\
22:Pagar Putih & 2 & 2 & 2 \\
23:Pojok Buhee & 2 & 2 & 2 \\
24:Kantin Hija & 2 & 2 & 2 \\
25:Nyo Nyo Mil & 2 & 2 & 2 \\
26:Seblak Nana & 2 & 2 & 2 \\
27:Salad by Sa & 2 & 2 & 2 \\
28:Cireng Domb & 2 & 2 & 2 \\
29:Bolen Geuli & 2 & 2 \\
30:Windys Riso & 2 & 2 \\
\hline
\end{tabular}

Dari tabel diatas dapat diketahui bahwa :

Apabila diinginkan dibentuk 4 cluster, maka

- Anggota Cluster 1 adalah UMKM 1 yaitu Wakacao

- Anggota Cluster 2 adalah katalogsweetshaley, Sedia Kopi, Jihan Salad, Kongkowrongok, Bagi Kopi, Selly Food, Dapur Vaedah. Roti Manis, Bubur Ayam, Sra'Cook, Milk Bar. Dapur Suka Suka, Kue Balok, Seblak Cihuy, Salad Buah Salada, Rumah Pasta \& Pastry, Seafood Cogadung, Kopi Doeloe, Pagar Putih, Pojok Buhee, Kantin Hijau, Nyo Nyo Milk, Seblak Nanay's, Salad by Sarah Kitchen, Cireng Domba, Bolen Geulis, dan Windy’s Risoles.

- Anggota Cluster 3 adalah Dapur Neng Monica

- Anggota Cluster 4 adalah Jameela Kitchen

Apabila dibentuk 3 cluster, maka

- Angggota Cluster 1 adalah Wakacao dan Dapur Neng Monica

- Anggota Cluster 2 adalah katalogsweetshaley, Sedia Kopi, Jihan Salad,Kongkowrongok, Bagi Kopi, Selly Food, Dapur Vaedah. Roti Manis, Bubur Ayam, Sra'Cook, Milk Bar. Dapur Suka Suka, Kue Balok, Seblak Cihuy, Salad Buah Salada, Rumah Pasta \& Pastry, Seafood Cogadung, Kopi Doeloe, Pagar Putih, Pojok Buhee, Kantin Hijau, Nyo Nyo Milk, Seblak Nanay's, Salad by Sarah Kitchen, Cireng Domba, Bolen Geulis, dan Windy's Risoles.

- Anggota cluster 3 adalah Jameela kitchen

Apabila dibentuk hanya 2 cluster maka :

- Anggota cluster 1 adalah Wakacao dan Dapur Neng Monica

- Anggota Cluster 2 adalah katalogsweetshaley, Sedia Kopi, Jameela Kitchen, Jihan Salad, Kongkowrongok, Bagi Kopi, Selly Food, Dapur Vaedah. Roti Manis, Bubur Ayam, Sra'Cook, Milk Bar. Dapur Suka Suka, Kue Balok, Seblak Cihuy, Salad Buah Salada, Rumah Pasta \& Pastry, Seafood Cogadung, Kopi Doeloe, 
Pagar Putih, Pojok Buhee, Kantin Hijau, Nyo Nyo Milk, Seblak Nanay's, Salad by Sarah Kitchen, Cireng Domba, Bolen Geulis, dan Windy's Risoles.

Tabel 4. 5 Dendogram Using Average Linkage

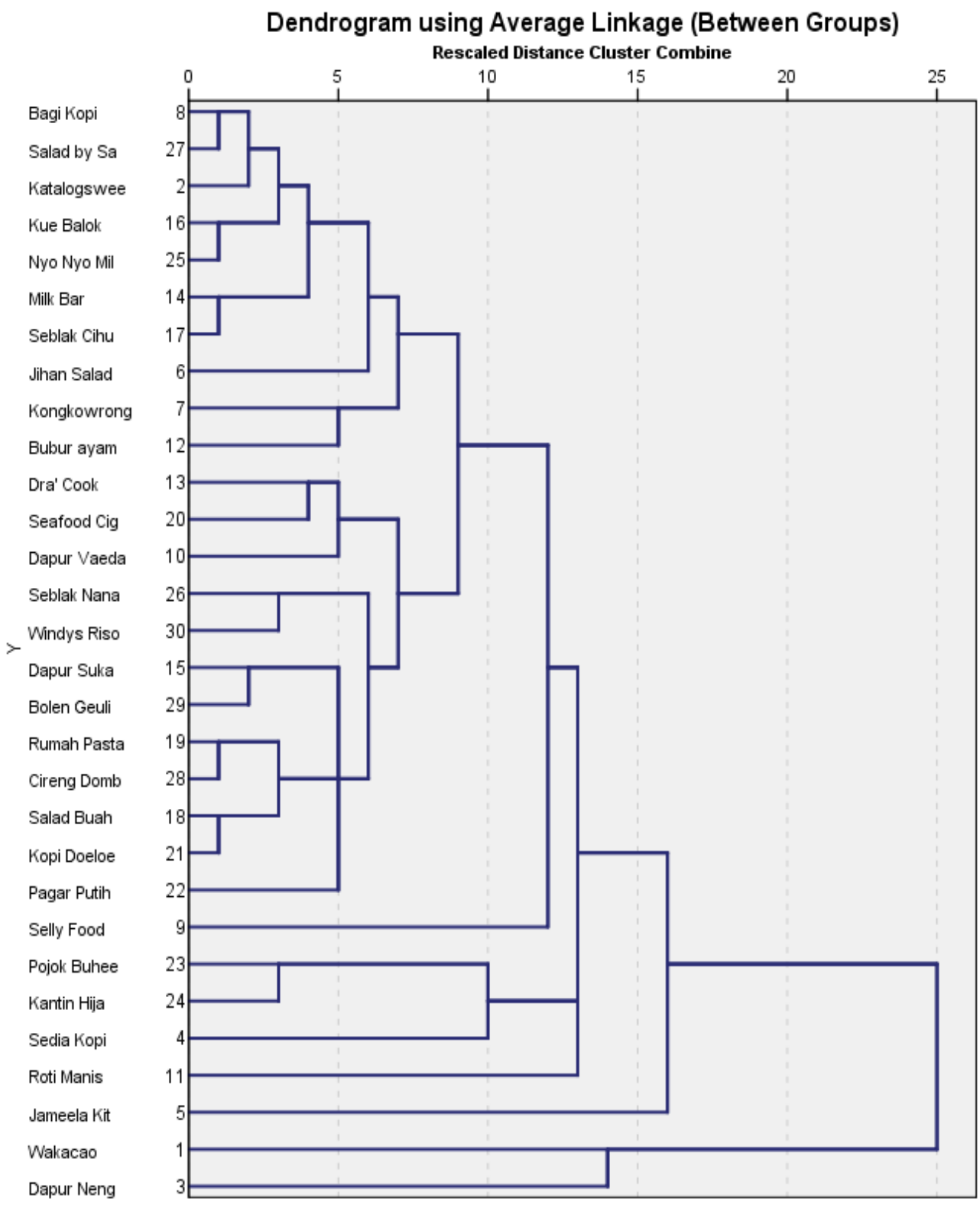

\section{KESIMPULAN}

Dari hasil penelitian yang telah dilakukan dengan total 30 responden dapat disimpulkan bahwa 97\% UMKM menggunakan sosial media sebagai alat untuk menyebarkan iklan media sosial yang sering digunakan adalah instagram, website, dan facebook. $40 \%$ menggunakan media elektronik seperti komputer dan handphone atau ada yang mengiklankan produknya melalui radio. 8\% melakukan promosi dengan menyebarkan informasi melalui mulut ke mulut, serta $2 \%$ menggunakan media cetak seperti, brosur dan 
pamflet. Sedangkan jenis iklan yang banyak digunakan oleh UMKM adalah iklan persuasif yang bertujuan untuk menarik minat calon pelanggan potensial atau konsumen untuk membeli produknya. Pentingnya dalam memilih media untuk melakukan pengiklanan yang berpengaruh penting sebagai alat penyebaran informasi kepada setiap konsumen.

\section{UCAPAN TERIMA KASIH}

Ucapan terimakasih ini ditujukan kepada STIE Ekuitas, Dewan redaksi Jesya Jurnal Ekonomi \& Ekonomi Syariah, serta semua pihak yang mendukung penulisan artikel ini.

\section{DAFTAR PUSTAKA}

Indriyanti, I. S., \& ilhalauw. (2002). Pengulangan Pesan Suatu Iklan Dalam Proses Pembelajaran Konsumen: Studi Terhadap Iklan Pasta Gigi Pepsodent . Jurnal Ekonomi dan Bisnis, Vol. 8, No, 1, 36-52.

Jefkins, F. (1997). Periklanan. Jakarta: Erlangga.

Khairani, Z., Soviyant, E., \& Aznuriyandi. (2018). Efektivitas Promosi Melalui Instagram Pada UMKM Sektor Makanan Dan Minuman di Kota Pekanbaru. Jurnal Benefita, Vol 3, No 2, 239-247.

Kotler, P . \& Keller, K.L. (2016). Manajemen Pemasaran Edisi 15e. PT. Indeks Kelompok Gramedia. Jakarta.

Lee, M., \& Johnson, C. (2011). Prinsipprinsip Pokok Periklanan Dalam Perspektif Global. Jakarta: Kencana.

Liliweri, A. (1992). Dasar-dasar Komunikasi Pemasaran. . Bandung: PT. Citra Aditya Bakti.

MacKenzie, S. B., \& Lutz, R. J. (1989). An Empirical Examination of the Structural Antecedents of Attitude toward the Ad in an Advertising Pretesting Context. Journal of Marketing, Vol. 53, Issue. 2, 48-65.

Nielsen Putting it All Together, "Nielsen Newscast No.4 (1985) : 6 Courtesy of Nielsen Newscast

Rina, S. N. (2014). Pengaruh Daya Tarik Iklan Dan Frekuensi penayangan Iklan Terhadap Intensi Pembelian Happy Call Lejel Home Shopping. Jurnal Kompetitif, Vo3, no, 2, 133 149.

Shimp, T. A. (2003). Periklanan Promosi Aspek Tambahan Komunikasi Pemasaran Terpadu. Jakarta: Erlangga. 
Shimp, T. A. (2014). Komunikasi Pemasaran Terpadu Dalam Periklanan dan Promosi. Jakarta: Salemba Empat.

Sihombing, Indra Jaya. 2010 Mengemas Bahasa Iklan. Suara Merdeka, 3 April 2010, h.1

Tjiptono, F. (1997). Strategi Pemasaran. Yogyakarrta: Andi. 